\title{
TOWARDS MODERNIST COLLECTING: SOME European Practices of THE LONG TERM
}

Susan Pearce

The beginning of modernist collecting, and, of the particular kinds of knowledge and experience which it embodies are usually considered to begin within the fifteenth century, where interests concentrates on the accumulations of the Medici, and upon the cabinets of curiosities, which begin to appear, as the century draws to a close. However, this early modern collecting practice did not crystalize out of nothing. The standard procedures of historical investigation can suggest some obvious predecessors: the collections of relics and treasures acquired by the great medieval churches and princes; the collections of Greek art acquired by first century and later Romans; and the material beld in Greek temples, described for us by Pausanius. But underlying all this collecting activity it is perhaps possible to discern some characteristics of the European tradition which inform collecting, and make it likely that modernist collecting, when it finally comes into being with the rest of modernist practice, will take the shape and significance which it has done. ${ }^{I}$

This paper $^{2}$ endeavours to single out some of these fundamental European characteristics, and to suggest why they are significant. There are many related issues which cannot be addressed here, and these include a definition of collecting, a view of what constitutes 'Europe' and its 'tradition', and the significance which this may have in a broader context. These are all very important themes, which will be discussed at befitting length elsewhere. Meanwhile, this discussion of some longterm European practices, in Braudel's sense of the term (see, for example, Bintliff 1991), and their relationship to collecting practice, is offered here as a contribution to the debate. 
SUSAN PEARCE

\section{OATHS AND ORDEALS}

The work of a number of linguists, and particularly of Thomas Markey, has given us a significant insight into the nature of European society which has a bearing on the matter in hand, and this revolves around its fundamental orientation as an oath/ordeal organisation rather than as a totem/taboo organisation, regarded by a broad anthropological consensus as two basic socio-cultural types which are found in complementary distribution and seldom overlap. Totemism has been the subject of such intense anthropological speculation that the history of it as an idea is more-or-less the history of anthropology as such, and Markey gives a helpful summary of this history in his 1985 paper. He suggests

A simple yet suitably broad and generally acceptable, working definition of totemism might well assume the following form. Totemism is the realisation of a particular, but generally mystical (or otherwise numinous), relationship between the members of a given social (typically kinship) unit and a natural object or group of objects (e.g. heavenly body, a plant, animal, or mineral or even meteorological phenomena) with which that unit is usually characteristically associated and from which it derives its name. [---]

But perhaps the most significant attribute of totemism is that it consists in a projection of mental attitudes on natural objects. However, that very projection, that very bridging, which asserts a continuity between culture on the one hand and nature on the other hand, is never subjected to experimental validation, nor could it be, and even if it were attempted it would defy such validation. A certain fish is, for example, equated with or classified as moral, boars with/as brave, diamonds with/as ethi- cal, and so on. But what probative test is there to demonstrate that boars are brave and diamonds are ethical? This is metaphorical thinking and a 'symbolic' logic of equal but opposite (e.g. left vs. right, male vs. female) that classifies by sentiment rather than function. (1985: 181).

Markey goes on to draw attention to the fact that

Systemically totemism is normally, perhaps even naturally, correlated with tabu. Tabu confers corrective significance on totemism; it is the police force of totemism and its boundary condition. The correlation of totemism with tabu, an undeniable empirical fact for the vast majority of totemizing cultures, gives rise to what we here term the totem/tabu or t/t-paradigm (1985: 181)

Clearly, it is the mystical/numinous character of totem and tabu which provides its psychic energy and defines the kind of world outlook which such a society is likely to have. Bertrand Russell has defined mysticism as possessed of four hallmark properties:

1) it invokes intuition alone and rejects discursive logic; 2) it is holistic rather than atomistic and isomorphically correlates all differences as integrated parts of a larger whole, of a cosmology, of a Weltanschauung entitled the Universe; 3) it denies Time and claims to play itself out in an all-embracing synchronic present with no meaningful past and little predictive future (other than the dire consequences of breaking a tabu, hence the policing/governing nature of tabu as a correlative of totemism); and 4) it views evil as mere (personified) appearance: there are only problems and no counter-examples in a world of mysticism devoid of principled, propositional or analytic and experimental logic. The probative basis of totemism is 
necessarily experiential, not experimental, logic. (Russell 1917: 1 - 31).

Totem/tabu societies, therefore, will have no interest in tests of validity, in the rational link between cause and effect or action and consequence, or in the nature of historical sequence. They will see the world as an undivided unity in which each fraction is part of the wholeness of things, perceiving no dualities, whether between man and the natural world, between man and matter, word and object, or right and wrong, other than as a matter of sacred transgression.

Markey, drawing on data embedded in the Human Relations Area Files held at the University of Michigan, suggests that the complementary paradigm to totem/tabu should be that of oath/ordeal, and that, as a matter of social and historical fact, it is to this paradigm that European society, past and present, seems to belong, some cultural admixture not withstanding. Like totem/tabu, oath/ordeal possesses its own kind of logic in the structure of oath, guaranteed by its own cosmological sanctions embodied in ordeal. Here, oath is defined as 'a formal invocation to gods/men to witness the contested validity of acts or intentions'. Characteristically, oaths adopt a formula, which carries the legitimatizing weight of precedent and is uttered in special places and at special times, in relation especially to the adjudication of guilt and innocence. The total familiarity with which we ourselves hear utterances like 'I swear I am innocent', or 'I swear before almighty God that what I say shall be the truth, the whole truth and nothing but the truth' bear witness (sic!) to the mindset of which these sayings are a part.
There is abundant evidence for related ordeal practices in the European past, including medieval and later trials by fire or by water (in the 'floating' of witches), the use of riddles as tests, and, of course, trial by single combat.

The oath/ordeal paradigm involves the notion of individual rights and responsibilities, since only a single person can perform oaths and ordeals, and the corresponding notion of the rest, who hear, see and judge. It sets up a dichotomy between word and object, between man and the material world which rejects the mystical unity of all things in favour of a sense of separations which hinge on pairs like true: false; supported by previous events : unsupported; proven by successful defence/ordeal : unproven; genuine : deceitful; innocent : guilty, and so on. It carries the seeds of a potential development of moral and social philosophy, logic and scientific experiment, analytical history, and most significantly for our present purposes, a particular relationship to the material world, which is regarded as 'other' and therefore as a fit arena for the exercise of the analytic qualities just outlined.

\section{KINSHIP AND PROPERTY}

In 1982 Leach wrote; 'When you read anything that any anthropologist has written on the topic of kinship be on your guard. The argument may not mean what you think; the author himself may not have understood what he is saying' (1982: 137 - 8). When this awful warning is linked with the difficulties of reconstructing what kinship systems may have been like in the remote past and linking this with more recent and contemporary situations, 
SUSAN PEARCE

90 and with the undoubted fact that nonanthropologists usually find the whole subject arid and unhelpful, it will be seen that is a difficult subject with which to grapple. However, in spite of all the thronging difficulties the fact remains that how a society sees its pattern of marriage and family relationships creates an essential part of its social character, and there are reasons for thinking that the broadly European system has, and for a long time has had, particular characteristics, especially as these effect the property-owning and collecting classes, which have played a significant role in defining long-term mentalités, particularly in relationship to notions about the material world.

The most comprehensive study of European kinship is that produced by Friedrich (1966) who was able to draw on a long tradition of previous study (e.g. Crosland 1957; Thieme 1958) and criticism by social anthropologists like Goody (1959). Friedrich has brought together both a large body of European data drawn from textural and linguistic study and theories of kinship semantics drawn from social anthropology, and used these to suggest what can be determined about early Euro- pean kinship in relation to immediate blood relationships, the extended family and the relationships through marriage.

Friedrich suggests that across the European language family the words for blood kin suggest a general and early recognition of the relationship set out in fig 1. Similarly, the words for relations through marriage, that is affines or (as we say) in-laws, suggest the broad existence of eight special terms, of which five were normally used by a woman when speaking of her husband's close blood relatives. From this Friedrich infers that the terms imply that on marriage the girl removed from her own blood kin to the familial group of her husband's father, and this fits with other early textual evidence which shows a great concentration of power in the father's hands, giving us an extended family of patriarchal type. Further evidence allows the suggestion that quite often the patriarchal family formed a physical household and associated field rights held by the father, where everybody lived (patri-local) and descent was reckoned in the male line (patri-linear) (1966: 14 23). All this produces a system which is deeply familiar to modern European men

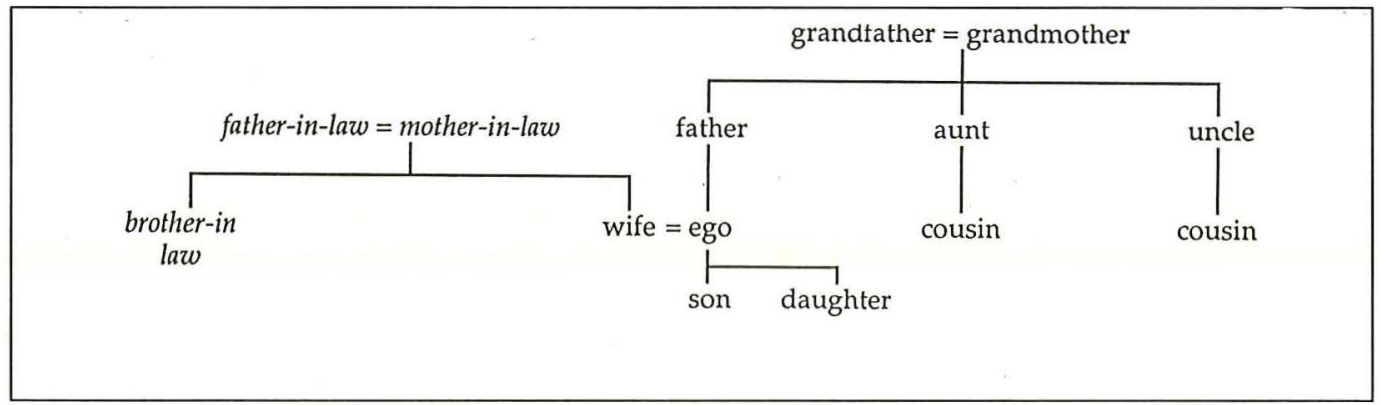

Fig. 1. Characteristic European kin and affine relationships. Terms are in relation to ego. Ego's affines are in italics. 
and women, especially if their appreciation of it has been sharpened by a taste for nineteenth century novels. Each of us would be wholly unsurprised if, on drawing up our own immediate family tree, it looked very much like that shown in figure 1 , and the same is broadly true of any modern European from Cork to Moscow.

Europe is not the only society in the world organised in terms of this sort of structure, but it is probably fair to say that such structures are relatively unusual. To quote Leach again

In a great many social systems the only fully legitimate marriages are those in which the bride and bridegroom are not only already kin but kin of a specific category such as, say, that which includes the relationship mother's brother's daughterlfather's sister's son. The rules are formally protected by supposedly powerful religious taboos, breach of which will result in supernatural punishment for all concerned. (Leach 1982: 144)

In these social systems, in other words, marriage between cousins of one kind or another is regarded as desirable. This gives us the sort of family tree set out in figure 2 , which relates to no actual society and is ludicrously over-simplified, but in its general shape serves to show how unfamiliar this system is to the European mind, and how different are some of its implications to those to which Europeans are accustomed.

To speak like this about European kinship is clearly to sketch a paradigm, rather than to discuss actual historical societies, which present an extremely confused picture across time and space. In particular, it is necessary to draw out what the formal kinship structures cannot show, the fact that in western Europe in general, and perhaps in England in particular, the capacity of women to own goods and property in their own right, by inheritance or purchase, runs back a long way into early medieval society. Similarly, in these societies, in many situations a property-holder (of both land and goods) had no inevitable heir and could leave his property by will as he wished, an approach which weakened the position of the eldest son and strengthened that of his junior siblings (MacFarland 1978). Nevertheless, the point here is not the many variations or deviations which may be played on the theme, but the theme itself: that, now and in the past there is an approach to marria-

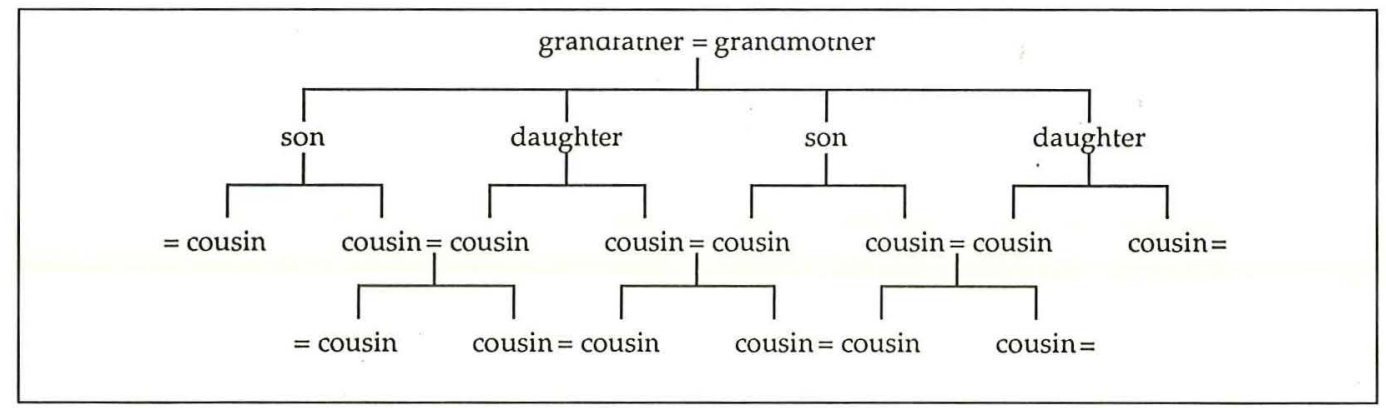

Fig 2. Schematic plan of one possible version of cross-cousin marriage. 
ge, inheritance and kinship which is identifiably European. This pattern has played an important part in social navigation and it is to this that we must now turn.

A system of cousin marriage, that is a marrying-in endogenous system, tends to create a vertical or monolithic structure in which the family resources are kept within the family, and can be shared out amongst all its members according to custom. By contrast, an exogamous or marrying-out system, like the European one, produces a relatively weak vertical structure and a relatively important horizontal one, in which family relationships straggle away into an extended series of affines. This has two important consequences. The goods that have been associated with a marriage, whether as a dowry provided by the girl's parents to go with her or bride-wealth provided by the man's family to go to her parents, will be lost to which ever family is making the provision because the two groups are not blood kin. This means that goods can circulate in such a society in a much less regulated and more random way than is often possible. Coupled with this has been a range of heirship strategies which operated at various times and places, but one stands out as particularly significant especially for the propertied classes in England and other parts of Western Europe. In order to retain a solid core of wealth within one family line it is necessary to create some inalienable property rights, of which the most obvious is the concentration of heirship in the eldest son, a strategy which Roman society embraced and bequeathed to later generations, and which may have operated earlier in some groups. This, however, has the result, another European classic, of crea- ting sequences of younger sons who although educated as gentlemen, have no visible means of support and must make their own way in the world.

The effects of this have probably been enormous. There is a very real sense in which a substantial element in the later (and perhaps some of the earlier) history of Europe is the history of portion-less younger sons who have always had to move on, open up new lands, look to acquire a well-dowered female, or take to commercial ventures. They have contributed considerably to the restless, aggressive, acquisitive character, which, for better or worse, is typical of Europeans. Their existence is part of the reason why European trade, industry and colonisation developed as it did. Europeans are accustomed to the idea that, because cousins are not booked to each more-or-less in their cradles, the marriage market operates much like any other market. The potential choice of marriage partner is very free and so very competitive, and this has helped inspire both our notion of romantic love with all the specially-orientated forms of production which this has entailed, and a steady but ever-shifting pattern of the accumulation and dispersal of material goods. In sum, one of the effects of the European kinship pattern has been to create a society in which, over a long period, material goods have been significant in a way which transcends their universal relationship to human needs, to encourage the inventions of ways in which the range and number of goods can be increased, and to create habits of object accumulation; and with all of this goes a mind-set materially attuned. 
HOARDING AND GIVING, HERE AND IN THE OTHER WORLD

The imagination of the early medieval world, both Germanic and later Scandinavian or 'Viking', was dazzled by the notion that heroic deeds are matched by splendid objects, that the 'imperishable fame' of the hero which shall be sung of to the end of the world, in the phrase which stands at the roots of recorded European consciousness, (Watkins 1982), shall be met with 'honourable gifts', a phrase which, as we shall see, may occupy a similar crucial place in the imaginations of those who used it. Splendid gifts were given from one man to another, sometimes from man to the gods, and sometimes from man to a dead hero: all of these forms stand within a long-continuing tradition which seems to run back into European prehistory, and all require analysis. We can come close to experiencing what the splendid objects were by considering the goods placed in the seventh century royal ship burial at Sutton Hoo, England with its sword, shield and helmet, dishes, ceremonial drinking horns and gold, enamelled purse filled with gold coins (on display in the British Museum).

In this tradition, together with kin, 'honourable gifts' constituted perhaps the most significant social bond. Markey has shown that the word for such gifts in Beowulf (Old Saxon), methom, derives from an inherited Germanic *maipm, which occurs in appropriate forms in some (but not all) early Germanic languages, and was 'the term par excellence of gift/exchange' in the early medieval Germanic world, part of the language of epic and of the primitive economy of heroic society 'but hardly anywhere in active use by the ninth century' (Markey 1990: 351). Markey suggests that *maipm 'unambiguously points to an underlying pre-Primitive Germanic *moitm -', a usage which might take us back to at least the later centuries BC. The word methom, especially in Beowulf, is particularly associated with gemaric as the context for gift exchange (maéne still carries the idea of 'well-endowed' in its modern English descendant as, for example, in our phrase 'a man of means'). In Beowulf gemaene means something like 'dutifully', honourably, given' and Markey suggests that this reflects a pre-Primitive Germanic *moitmos ghomoinis, which we may render as 'honourable gift exchange'. Markey notes that this corresponds approximately to a Common Italic *donom da-ldo, and suggests that here we have tracked down a formula of early Northern European poetic diction which encapsulates a crucial social practice, like that represented by the culturally akin 'imperishable fame'. The recorded practices of migration age princes, therefore, throw their light backwards into prehistory, as well as casting their shadow before.

What this light shows us becomes clearer when we consider two other words which also belong with notions of 'reward', mizdo and laun. As Benveniste has shown mizdo, while ultimately related to maipm, meant 'worldly reward' while laun meant 'providential' or 'heavenly reward' and as such had a gathering tendency to be used in Christian contexts. Markey (1990: 352) sets out the potential relationship between the three words in an interesting paragraph which deserves quoting in full: 
SUSAN PEARCE

94 'Now, if, as seems highly likely, laun originally defined providential, divine rewardltreasure in opposition to mizdo (and congeners) as the expression of secular reward/treasure, payment gained by contest, conquest, or work, then where does maipm fit into this continuum and what, if any was its relationship to laun on the one hand and or its formal sibling mizdo on the other hand? then too, in addition to the exigencies of a conversion literature as outlined above, why did maipm - vanish? Why, too on its deathbed in that literature, was it so readily ambiguous (both secular and divine) and unable to make a transition to one pole (laun) or the other (mizdo)? We suggest that, as the original expression for courtly gift/exchange within the communitas, maipm occupied a pivotal position midway betweenly totally $\{+$ secular/-divine $\}$ and totally $\{$-secular/+divine\}, indeed just as the princeps as communal leader (Goth piudans) and addressee of the maipm-ritual occupied the same position:

$$
\begin{array}{ccl}
\text { laun } & \text { maipm } & \multicolumn{1}{c}{\text { mizdo }} \\
+ \text { divine } & + \text { - divine } & \text { - divine } \\
- \text { secular } & +- \text { secular } & \text { - divine } \\
\text { - secular } & + \text {-secular } & + \text { secular }
\end{array}
$$

(Markey 1990 : 352)

We can conclude that maipm, honourable gifts and the weapons, helmets and ornaments of gold and jewels inseparable from the idea, stood at the critical threshold between two worlds, and that the act of exchange between prince and follower constituted a rite of passage which acknowledged and confirmed mutual obligations, a character which collected material was long to maintain.

\section{HEAVENLY REWARDS}

Parallel with this heroic world, feeding upon it and ultimately superseding it, ran another mode of accumulating collected material, one which inherits most of what had gone before, and fuses the strands together through the catalyst of Christian practice. The idea that the burial places and the corporeal relics of Christian holy men and women carried significance for the living was well-established by around $\mathrm{AD} 400$, the end of Imperial Rome in the west, and the beginning of a Christendom whose theocratic power was exercised by a church hierarchy descending from, and modelled upon, the old imperial, bureaucracy. Historically, this practice arose from the persecutions which the early Church suffered, and from the martyrs' relics which resulted. But far more was involved than the simple act of remembrance and the moral encouragement which it provided. The holy graves where relics were buried or, eventually, enshrined, mediated between God and men. They were the locus where Heaven and Earth touched, where this world and the other world met.

Churches which possessed holy relics came to accumulate earthly treasures which matched those spiritual, and those which did not took pains to acquire both: heavenly treasure and the earthly riches which surrounded it seemed to have been indissolubly mixed in the medieval mind. The kinds of objects involved may be seen by the Cross of Lothair, made in Cologne about 1000 in the possession of the cathedral church of Aachen. It is a magnificent piece with goldsmiths' filigree work and mounted precious stones and incorporated both the rock-crystal seal of Lothair II of Lotharingia (855-869) and, in its centre, a superb cameo of the Emperor Augustus (31 BC - AD 6) (Beckwith 1964: 140-142, 259-60). A classical gem, an aquamarine intaglio showing the portrait of Julia, 
daughter of the Emperor Titus (AD 79-81) formed the top jewel of the elaborate jewelled piece known as the Crista or Escrin de Charlemagne (although probably the gift of Charles the Bold) in the possession of the abbey of St Denis, where the relics of the saint and his companions were held (Panofsky - Soergel 1979: 190). These two examples, chosen more-or-less at random from the great wealth of possible illustrations, give an idea of the richness involved.

As we have just said, relics were the place where this world and the Otherworld met, and this explains why they were able to attract so much collected treasure to themselves and their churches, but their nature needs more explanation. Relics belong within that quite large class of objects which in life were part of a living human or animal, but which in death are turned into things. Relics are objects which are both persons and things, and their corporeal reality - frequently obvious to the eye as a limb or a skull - reinforces their double condition and ties them to the experienced 'real' world of time and space. As persons they are true saints living with God; as relics they are documents for understanding the world. The way of understanding was through an appreciation of God's intervention in the affairs of this world, of knowing how sometimes the Divine could directly affect the mundane. The importance of life lay not in diurnal regularities but in anomalies, strange occurrences, interruptions and miracles, and of these miracles the relics themselves were physical proof. This notion was to cast a long shadow before it, as we shall see, but for the present, let us express the essential nature of the relic in a simple semiotic form shown in figure 3. It is the relics' documentation of the miraculous which stimulated the great thesaural activity which they stimulated.

We can now see that the treasures of the great early medieval churches gather together most of the threads which have characterised object accumulation in the preceding centuries, and weave them together in a form which will greatly influence the shape of things to come. The treasures belong to God and to the holy ones who dwell with him. Consequently, they themselves are things set apart, both holy and dangerous, ominous in their power. They are gifts to God and to the mighty dead whose graves and shrines occupy the imaginative place which burial mounds like Sutton Hoo had held in the minds of those northern barbarians now gradually converting to Christianity. The giving of

\begin{tabular}{|c|c|c|}
\hline \multicolumn{3}{|c|}{ Relic } \\
\hline & $\underline{\text { Signifier }}$ & $\underline{\text { Signified }}$ \\
\hline$\underline{\text { Matter }}$ & Corporeal survival of holy body & $\begin{array}{l}\text { Document of God's miraculous } \\
\text { intervention }\end{array}$ \\
\hline Content & Presence of saint in Heaven & $\begin{array}{l}\text { Possibility of miraculous intervention } \\
\text { on behalf of worshipper, bringing } \\
\text { him to Heaven }\end{array}$ \\
\hline
\end{tabular}

Fig 3. Semiotic analysis of 'relic'. 
96 gifts at the altar is still honourable and still a rite of passage in which the divine and the mundane are brought together and the status of the donor is changed, although, as Markey has shown, the Church found it necessary to make a clear distinction between old Pagan and new Christian practice in which the older vocabulary of meithom, came to mean 'earthly reward and laun to mean 'heavenly/true reward'. Gifts to the church, like pagan gifts to the dead or to Otherworld powers, are valuables withdrawn from circulation, frozen assets, to be seen primarily as creating a relationship between man and god, from which proper relationships between men will depend. Oaths once sworn upon Thor's rings will now be sworn upon the holy bones in their reliquaries of gold and gemstones.

From the old northern world the church treasures took notions of gift exchange, the depositing of treasure with the dead and at sacred places, and the link between royal hall and royal church, usually built very or relatively close together in the early medieval world. They succeeded the earlier temples, also, as repositories of community memory, materially expressed. The link between the old imperial world and the new devotion was sometimes made explicit in the value accorded to ancient cameos and similar pieces. From the world, also, come notions of the significance of the physical means of the holy dead, notions, perhaps, with their roots in ancient practice. The early medieval church treasures are, then, a meeting point of significances. In appearance, they were immensely impressive: treasure withdrawn from the working world still works upon through the vision of eye and mind.

\section{SOME CONCLUSIONS}

This brief review of some important longterm elements in European thought and practice has important implications for the ways in which collections have been formed, and the rationale from which they spring and to which they contribute. The suggestion that European culture belongs within the oath/ordeal social paradigm focuses attention on the European tendency to regard time and space as properties capable of classification, and consequently to be deeply interested in assessment, measurement and the material evidence which can give these qualities observable creativity. It is arguable that this paradigm is one important source of the European 'scientific' mentality, which then, of course, had such an incalculatory impact upon the world as a whole. Seventeenth and eighteenth century science, and to a certain extent, contemporary science also, depends upon material evidence, just as the notion of 'evidence' underpins this whole mentalité. The materiality of collected specimens, and the ways in which these have come to be seen to be susceptible to classificatory principles and procedures, is an inevitable part of this mental attitude, and the making of collections, therefo$r e$, is an integral element within it.

The notion of spatial and chronological classification bears a distinct relationship to the practice of keeping relics, for here we have the notion of the 'real' presence of the dead created by their remains which come to us from the past. It is an attitude which, in the fullness of time, will create all the collections which have to do with 'famous' people, and also alternatively, those which are usually described in museums as 
social history, and have to do with the ordinary people of the past. At the same time, the 'anomaly', the 'miracle' aspect of relics, linked with the notions of sequential classification which we have just discussed, prepares the way for fruitful ideas of 'difference' and 'oddity', the strangeness which needs exploration. These ideas were powerful in the cabinets of the sixteenth and seventeenth century, and have made their own contribution to contemporary science.

Relics have another resonance. They, and the treasures which surrounded them, belonged in the churches, often the royal churches, of the medieval past, and there is a clear historical chain which links these palaces and chapels to the earliest museums of the Renaissance, and so to the state and civic museums of the modern world. Such a chain can be traced clearly in the royal and national collections of the Scandinavian world, and also in those of a number of the German rulers. In the contemporary world museums possess the same kinds of prestige and assert the same kinds of cultural power which once belonged to prince and priest.

One significant aspect of this cultural power is the notion that important collections are inherently sacred. They are detached from the mundane world and held in a sort of special suspension, above and beyond commodity or valuation in commodity terms. Sometimes these collections are held to possess aesthetic and craft excellence. Sometimes, particularly in scientific or historical collections, they possess the authority of knowledge, itself a product of material classification. As we saw in our discussion of gift-giving, the transmission of treasure was a rite of passage; the sacred force of the objects, poised between this World and the Otherworld has the power to transform, to change identities and relationships. The possession of collections retains this power. Individuals are made different by virtue of the artistic or scientific collections which they own and (presumably) administer, and this is so well understood that it is a powerful motive behind the gathering of collected material.

Characteristic European practices of kinship and inheritance inform all these other social notions, however difficult the notion of 'characteristic' may be. They have helped to create a materially-based society in which the accumulation of wealth by individuals is extremely important, because this is the only chance many people have to make a living. Kinship and inheritance practices feed into notions of social fluidity and individual choice and effort, which have contributed towards the peculiarly European forms of long-distance contact and exchange, commerce, and, ultimately, the proliferation of manufactured goods which we usually call the industrial revolution, particularly as it was experienced in Britain and other parts of Western Europe. This, in its turn, has helped to foster the western notion that 'you are what you own', an idea quite alien to many of the world's communities. All these practices are likely to encourage collecting as a form of object investment, and as an aspect of personal wealth and prestige.

So brief an analysis leaves much unsaid, and inevitably treats each aspect of social practice here discussed as more monolithic and less subtle than it probably ever was. Nevertheless, we can see a tradition in the long-term in which a number of elements interlock to give us the major modernist collections which we see around us, inside 
98 and outside museums. Materiality is inherent in the long-term mentalité of European society, because this depends upon the twin notions of personal effort and accumulation and the idea of evidence, effort and accumulation and the idea of evidence, arrived at by processes of discrimination in time, space and form. Unsurprisingly, therefore, treasure hoarded and dispersed to be hoarded again, achieves a kind of divinity, which from at least the beginning of the European bronze age is linked with the feeling that such pieces make appropriate gifts to the dead and to the gods. From such ancient thoughts, the churches, treasures and relics of the medieval world drew their strength, and in their turn passed their power to modern collectors and museums. When we look at collections on display we should see not only their local or immediate significance in terms of history or quality shallowly conceived; we should see also how they are a realisation of deep rooted social practice. When we look at European collections, we are looking at the European mind.

\section{NOTER}

1. In the introduction references are made to Pearce 1992: 14-35, Strong 1973 and Levi 1971.

2 . The paper forms part of a larger project which investigates the European tradition of collecting practice, the poetics of collecting, and the politics of collecting, to be published by Routledge in 1995 .

\section{LITTERATUR}

Beckwith, J., 1964, Early Medieval Art, London. Bintliff, J. (ed.), 1991, The Annales School and Archaeology, Leicester.
Crossland, R.A., 1957, Indo-European Origins: the linguistic evidence, Past and Present, 12: 16-46.

Friedrich, P., 1966, 'Proto-Indo-European Kinships', Ethnology, 5: 1-36.

Goody, J., 1959, 'Indo-European Society', Past and Present, 16: 88-92.

Leach, E., 1982, Social Anthropology, London.

Levi, P. (ed.), 1971, Pausanias: Guide to Greece, London.

MacFarlane, A., 1978, The Origins of English Individualism, Oxford.

Markey, T., 1985, 'The Totemic Typology', Quaderni di Semantica, 6, 1: 175-94.

Markey, T., 1990, 'Gift, Payment and Reward Re-visited', in Markey, T. and Greppin, J. (eds.), When Worlds Collide: Indo-Europeans and Pre-IndoEuropeans, Ann Arbor: 345-362.

Panofsky E., 1979, Abbot Suger on the Abbey Church of St-Denis and its Art Treasures, Princeton.

Pearce, S.M., 1993, Museums, Objects and Collections, Leicester.

Russell, B., 1917, Mysticism and Logic, New York. Strong, D.E., 1973, 'Roman Museums' in Strong (ed.) Archaeological Theory and Practice : Essays Presented to W. F. Grimes, London. 248 - 264.

Thieme, P., 1953, 'Die Heimat der Indogermanischen Gemeinsprache'. Abhandlungen der Geistes - und Sozialwissenschaftlichen Klasse, Akademie der Wissenschaften und der Literature, 535-610, Wiesbaden.

Watkins, C., 1982, 'Aspects of Indo-European Poetics' in Polome, E. (ed.), The Indo-Europeans in the Fourth and Third Millenennia, Ann Arbor: 104120.

Susan M Pearce är professor och leder for Department of Museum Studies, Leicester University, England. Hon har redigerat och skrivit många böcker, senast 'Museums, Objects and Collections' (1992).

Adr: Department of Museum Studies, University of Leicester, 105 Princess Road East, Leicester LE1 7LG, England. FAX +44533523960. 